\title{
Effect of aqueous extracts of some indigenous medicinal plants on sheath blight of rice
}

\author{
M. M. Islam and M. S. Monjil \\ Department of Plant Pathology, Bangladesh Agricultural University, Mymensingh-2202, Bangladesh \\ *E-mail: smonjil@yahoo.com
}

\begin{abstract}
Aqueous extract of some indigenous plant parts were evaluated for its efficacy to control sheath blight of rice. Six treatments were applied, viz. $\mathrm{T}_{1}$ - control (water spray), $\mathrm{T}_{2}$ - Tulsi (Ocientific tenuiflorum) extract (1:10), $\mathrm{T}_{3}-\mathrm{Nishinda}$ (Vitex negundu) extract (1:10), $\mathrm{T}_{4}$ - Thankuni (Centella asiatica) extracts (1:10), $\mathrm{T}_{5}$ - Biskatali (Polygonum hydropiper) extract (1:10) and $\mathrm{T}_{6}$ - Proud (Propiconazole @ 0.2\%) as a positive control. Effect of these plant extracts on percent tiller infection and percent relative lesion height of sheath blight of rice cultivar BRRI dhan 49 was determined at 55 , 75 and 95 day after transplanting (DAT). Number of infected tillers per hill differed significantly among the different treatments. The highest number of infected tillers was observed in control treatment. The lowest and statistically similar number of infected tillers was found in fungicide, Proud (Propiconazole)- and Biskatali- treated plots. Reduced number of infected tillers was observed in Tulsi, Thankuni and Nishinda. Highest percent tiller infection was recorded in control and lowest percent tiller infection was recorded in Proud and Biskatali, which were statistically similar. Nishinda, Tulsi and Thankuni had reduced tiller infection in compare to control. Percent reduction of tiller infection over control was achieved by proud followed by Biskatali. The highest lesion height was observed in control and lowest lesion height was found in Proud followed by Biskatali. The highest percent relative lesion height was recorded in control followed by Thankuni. The lowest percent relative lesion height was recorded in Proud preceded by Biskatali. Highest percent reduction of relative lesion height over control was achieved by proud followed by Biskatali. Thus, plant extracts of Biskatali, Tulsi, Nishinda and Thankuni are effective to control sheath blight of rice. Among the plant extracts, Biskatali showed highest control of sheath blight disease of rice.
\end{abstract}

Keywords: Rice, Medicinal plant extracts, Sheath blight, Control

\section{Introduction}

Rice (Oryza sativa L.) is one of the most important staple crops for a large part of the world's population, mainly in East, Southeast and South Asia (FAO, 2010). Yield losses due to diseases and pests are one of the major constraints in rice production. Rice crop is suffered by more than 40 diseases among which sheath blight is considered important fungal disease at various parts of rice growing areas of the world. (Latif et al. 2011). Sheath blight disease of rice caused by Rhizoctonia solani occurs in all rice growing areas worldwide (Ou, 1985; Savary et al. 2006). Yield losses of $14-17 \%$ have been estimated in different varieties during Aus, Aman and Boro seasons of Bangladesh (Shahjahan et al. 1986). Sheath blight may cause up to a $50 \%$ decrease in the rice yield under favourable conditions around the world (Zheng et al. 2013).

To manage sheath blight of rice, several techniques such as manipulation of agronomic practice, use of resistant varieties, application of fungicides and bioagent have been practiced. Most of the fungicides like Benomyl, Carbendazim, Chloroneb, Captafol, Mancozeb, Zineb, Edifenphos, Iprobenphos, Thiophanate and Carboxin had been found effective for the control of the disease under field conditions (Dash and Panda, 1984; Kannaiyan and Prasad, 1984; Singh and Sinha, 2004). Cultural or biological control involves comparatively less cost and it is not health hazardous and environmental friendly. Plant extracts with antifungal activity against a variety of fungi have been reported. Ashrafuzzaman and Khan (1992) reported that extract of Allamanda (Allamanda cathertica), Meheadi (Lawsonia alba) and Duranta (Duranta plumeiri) inhibited mycelial growth and sclerotial formation of Rhizoctonia solani. Rout et al. (2013) reported that Aegle marmelos extract had high antifungal activity against $R$. solani. Clove extract completely inhibited the growth of $R$. solani, $R$. oryzae, $R$. oryzae-sativae and Sclerotium hydrophilum (San-Aye and Matsumoto, 2011). Siam weed extract was found to be effective in reducing severity of blast, brown spot and bacterial leaf blight disease of rice (Khoa et al., 2011). Plant extracts contain metabolites including alkaloids, glucosinolates, indole, phenolics, phenylpropanoids, saponins, stilbenes and terpenoids have been reported to exhibit antifungal properties (Dixon, 2001; Lanzotti et al., 2012). Biskatali (Polygonum hydropiper) and neem (Azadirachta indica) were studied against insect pests (Amin et al. 2000, Akter and Jahan, 2013) and seed borne fungi (Ahmed et al. 2002, Ahmed et al. 2013, 
Indigenous medicinal plants on sheath blight of rice

Bhuiyan et al. 2013). Since these extracts were active against insect pests and fungal pathogens, thus, they might be potentially suitable for use in integrated pest management programs and could lead to development of new classes of possible safer disease control agents (Peshin et al., 2009). In the case of natural fungicides, low toxicity and high efficiency are necessary. The objective of this research was to determine the effect of the aqueous extracts of some indigenous medicinal plants on the reduction of sheath blight of rice.

\section{Materials and Methods}

The experiment was conducted at the Laboratory and in the experimental field of Department of Plant Pathology, Bangladesh Agricu1ltural University, Mymensingh. The experiments were carried out during from January, 2013 to April, 2014. Transplanted Aman rice BRRI dhan 49 was used as the test crop for the experimental plot. Thirty days old seedlings were transplanted, which were carefully collected from the seedbed previously raised in Bangladesh Agricultural University Farm, BAU, Mymensingh. Plant spacing of $20 \mathrm{~cm} \times 15 \mathrm{~cm}$ was maintained. Three to four seedlings used transplanted in each hill.

Six treatments were applied, viz. $T_{1}$ - control (water spray), $T_{2}$ - Tulsi (Ocientific tenuiflorum) extract (1:10), $\mathrm{T}_{3^{-}}$Nishinda (Vitex negundu) extract (1:10), $\mathrm{T}_{4^{-}}$Thankuni (Centella asiatica) extracts (1:10), $\mathrm{T}_{5^{-}}$Biskatali (Polygonum hydropiper) extract (1:10), T6-Proud (Propiconazole @.2\%). Plant extracts were prepared at 1:10 ratio of plant material and water (Islam et al., 2013). Briefly, sample of $100 \mathrm{~g}$ of each test plant was chopped into small pieces. Water $(500 \mathrm{ml})$ was added to chopped sample and was finally blended. The material was filtered through the cheese cloth. The filtered debris was soaked in water again. Total one litter extracts was volume by water. The $0.2 \%$ spray solution of the Proud was prepared by mixing the fungicide (proud) with water at a rate of $2 \mathrm{ml}$ of the chemical in $1000 \mathrm{ml}$ of water and was well. Hand sprayer was used to spray the plant extracts. Control plots were sprayed with water. Special attention was given to complete coverage of the plants with spray materials. Fungicide was sprayed twice, at 35 days and 60 days after transplanting. Data were collected from 55, 75, 95 days after transplanting. Data on the different parameters viz., Number of tillers per hill, Number of infected tillers per hill, Plant height $(\mathrm{cm})$ and Lesion height $(\mathrm{cm})$ of disease symptoms, were recorded from rice plant infected naturally. Relative lesion height (\%) and Reduction of relative lesion height over control (\%) were calculated.

Two times spray were done at 35 days and 60 days after transplanting. Sheath blight symptoms in rice were appeared about 30 days after transplanting of rice seedlings. Data were taken at 55,75 and 95 DAT. Incidence of sheath blight of rice was calculated in each plot by using the formula followed by Rajput and Bartaria, (1995). The percent relative lesion height was calculated by using the formula applied by Ansari (1995). Pathogen causing sheath blight of rice was isolated by incubating sheath blighted rice stems in sterilized moist chamber. Whitish sclerotia were grown in moist rice stem along with infected sheath. Sclerotia were transferred to PDA and then, pure culture of Rhizoctonia spp. were established.

The data on different parameters were statistically analyzed by using analysis of variance (ANOVA) technique to find out the level of significance. The effect of the treatments was compared by Duncan's Multiple Range Test (DMRT). The collected data were analyzed using a statistically computer package (MSTATC).

\section{Results}

\section{Effect of plant extracts on percent tiller infection of sheath blight of rice cultivar BRRI dhan $\mathbf{4 9}$}

For estimating the effect of plant extracts on percent tiller infection of sheath blight of rice cultivar BRRI dhan 49 , data on number of tillers per hill and number of infected tillers per hill were taken at 55,75 and 95 day after transplanting (DAT). At 55 DAT (Table 1), highest number of tillers per hill was found in Biskatali $\left(T_{5}, 10.37\right)$ followed by Proud $\left(T_{6}, 9.67\right)$ and lowest number of tillers per hill was found in Tulsi $\left(T_{2}, 7.40\right)$ followed by control treatment $\left(T_{1}, 7.67\right)$. Number of infected tillers per hill was differed significantly among the different treatments. The highest number of infected tillers was observed in control treatment (2.71). The lowest number of infected tillers was found in fungicide, Proud (0.90) and Biskatali (0.96)-treated plots, which are statistically similar. Reduced number of infected tillers was observed in Tulsi (1.13), Thankuni (1.36) and Nishinda (1.59). Percent tiller infection differed significantly 
among the different treatments ranged from $9.51 \%$ to $35.72 \%$. The highest percent tiller infection was recorded in control treatment $(35.73 \%)$. The lowest percent tiller infection was recorded in Proud $(9.51 \%)$ and Biskatali $(9.77 \%)$, which are statistically similar. Compare to control, Nishinda (14.52\%), Tulsi $(15.803 \%)$ and Thankuni $(16.78 \%)$ reduced tiller infection. Percent reduction of tiller infection over control was achieved by Proud (73.37\%) followed by Biskatali $(72.66 \%)$.

Table 1. Efficacy of some plant extracts on the tillers infection of sheath blight rice cv. (BRRI dhan 49) at 55 days after transplanting (DAT)

\begin{tabular}{lcccc}
\hline \multicolumn{1}{c}{ Treatments } & $\begin{array}{c}\text { Number of tillers } \\
\text { hill }^{-1}\end{array}$ & $\begin{array}{c}\text { Number of infected } \\
\text { tillers hill }\end{array}$ & $\begin{array}{c}\text { (\%) Tiller } \\
\text { infection }\end{array}$ & $\begin{array}{c}\text { (\%) Reduction of tiller } \\
\text { infection over control }^{-1}\end{array}$ \\
\hline $\mathrm{T}_{1}$ (Control) & 7.67 & $2.71 \mathrm{a}$ & $35.73 \mathrm{a}$ & - \\
$\mathrm{T}_{2}$ (Tulsi) & 7.40 & $1.13 \mathrm{e}$ & $15.80 \mathrm{~cd}$ & 55.76 \\
$\mathrm{~T}_{3}$ (Nishinda) & 8.20 & $1.59 \mathrm{c}$ & $14.52 \mathrm{~d}$ & 59.37 \\
$\mathrm{~T}_{4}$ (Thankuni) & 8.13 & $1.36 \mathrm{~d}$ & $16.78 \mathrm{c}$ & 53.03 \\
$\mathrm{~T}_{5}$ (Biskatali) & 10.37 & $0.96 \mathrm{f}$ & $9.77 \mathrm{e}$ & 72.66 \\
$\mathrm{~T}_{6}$ (Proud) & 9.67 & $0.90 \mathrm{f}$ & $9.51 \mathrm{e}$ & 73.37 \\
\hline Level of significance & $*$ & $*$ & & \\
\hline
\end{tabular}

Data represent the means of three replications. ${ }^{*}=$ Significant at $5 \%$ level of probability.

At 75 DAT (Table 2), the highest number of tillers per hill was found in Biskatali (10.93) followed by Tulsi (10.47) and lowest number of tillers per hill was found in control treatment (9.08). Number of infected tillers per hill differed significantly among the different treatments. The highest number of infected tillers was observed in control treatment (4.17). Statistically similar and lowest number of infected tillers was observed by Proud (2.08) and Biskatali (2.10). Percent tiller infection differed significantly among the different treatments ranged from $18.54 \%$ to $46.52 \%$. The highest percent tiller infection was recorded in control and the lowest percent tiller infection was recorded in Proud. Biskatali (21.77\%) and Tulsi (24.53) were found effective for controlling tiller infection. The highest percent reduction of tiller infection over control was obtained by Proud $(60.16 \%)$ followed by Biskatali $(53.20 \%)$. At 95 DAT (Table 3), effect of plant extract on number of tillers per hill was not differed significantly among the different treatments. On the other hand, number of infected tillers per hill and percent tiller infection were followed similar trends controlling the disease, where lowest infected tillers per hill and tiller infection was observed in Proud in compare to control.

Table 2. Efficacy of some plant extracts on the tillers infection of sheath blight rice cv. (BRRI dhan 49) at 75 days after transplanting (DAT)

\begin{tabular}{lcccc}
\hline \multicolumn{1}{c}{ Treatments } & $\begin{array}{c}\text { Number of } \\
\text { tillers hill }^{-1}\end{array}$ & $\begin{array}{c}\text { Number of infected } \\
\text { tillers hill }\end{array}$ & $\begin{array}{c}\text { (\%) Tiller } \\
\text { infection }\end{array}$ & $\begin{array}{c}\text { (\%) Reduction of tiller } \\
\text { infection over control }\end{array}$ \\
\hline $\mathrm{T}_{1}$ (Control) & 9.08 & $3.68 \mathrm{a}$ & $54.59 \mathrm{a}$ & - \\
$\mathrm{T}_{2}$ (Tulsi) & 10.47 & $2.21 \mathrm{de}$ & $24.66 \mathrm{~d}$ & 54.84 \\
$\mathrm{~T}_{3}$ (Nishinda) & 9.53 & $2.30 \mathrm{~cd}$ & $28.64 \mathrm{c}$ & 47.54 \\
$\mathrm{~T}_{4}$ (Thankuni) & 9.97 & $2.45 \mathrm{c}$ & $30.62 \mathrm{c}$ & 43.92 \\
$\mathrm{~T}_{5}$ (Biskatali) & 10.93 & $2.00 \mathrm{ef}$ & $20.62 \mathrm{e}$ & 62.22 \\
$\mathrm{~T}_{6}$ (Proud) & 9.82 & $1.85 \mathrm{f}$ & $22.89 \mathrm{de}$ & 58.09 \\
\hline Level of significance & $*$ & $*$ & $*$ & - \\
\hline
\end{tabular}

Data represent the means of three replications. ${ }^{*}=$ Significant at $5 \%$ level of probability.

Table 3. Efficacy of some plant extracts on the tillers infection of sheath blight rice cv. (BRRI dhan 49) at 95 days after transplanting (DAT)

\begin{tabular}{lcccc}
\hline \multicolumn{1}{c}{ Treatments } & $\begin{array}{c}\text { Number of } \\
\text { tillers hill }^{-1}\end{array}$ & $\begin{array}{c}\text { Number of infected } \\
\text { tillers hill }\end{array}$ & $\begin{array}{c}\text { (\%)Tiller } \\
\text { infection }\end{array}$ & $\begin{array}{c}\text { (\%) Reduction of tiller } \\
\text { infection over control }\end{array}$ \\
\hline $\mathrm{T}_{1}$ (Control) & 7.68 & $4.17 \mathrm{a}$ & $46.52 \mathrm{a}$ & - \\
$\mathrm{T}_{2}$ (Tulsi) & 9.47 & $2.28 \mathrm{e}$ & $24.53 \mathrm{e}$ & 54.84 \\
$\mathrm{~T}_{3}$ (Nishinda) & 8.53 & $2.77 \mathrm{c}$ & $35.56 \mathrm{c}$ & 47.54 \\
$\mathrm{~T}_{4}$ (Thankuni) & 8.07 & $2.60 \mathrm{~d}$ & $32.55 \mathrm{~d}$ & 43.92 \\
$\mathrm{~T}_{5}$ (Biskatali) & 9.93 & $2.10 \mathrm{ef}$ & $21.77 \mathrm{e}$ & 62.22 \\
$\mathrm{~T}_{6}$ (Proud) & 8.82 & $2.08 \mathrm{f}$ & $18.54 \mathrm{~g}$ & 68.09 \\
\hline Level of significance & $*$ & $*$ & ${ }^{*}$ & - \\
\hline
\end{tabular}

Data represent the means of three replications. ${ }^{*}=$ Significant at $5 \%$ level of probability. 
Effect of different plant extracts on lesion height and percent relative lesion height of sheath blight of rice cultivar BRRI dhan $\mathbf{4 9}$

Effect of different plant extracts on plant height, sheath blight infected lesion height, percent relative lesion height of sheath blight of rice cultivar BRRI dhan 49 was detected at 55, 75 and 95 DAT. Plant extract's effect on plant height was not found statistically significant at 55, 75 and 95 DAT. Lesion height of sheath blight infected rice plant and percent relative lesion height differed significantly among the different treatments. At 55 DAT (Table 4), highest lesion height (11.54) was observed in Control followed by Thankuni (7.83) and lowest lesion height (4.28) was found in Proud followed by Biskatali (5.31). The percent relative lesion height ranged from 13.76 to 42.69 . The highest percent relative lesion height was recorded in untreated control followed by Thankuni, Nishinda, Tulsi, Biskatali and Proud. Statistically similar results were observed in Nishinda and Thankuni sprayed plots. Highest percent reduction of relative lesion height over control was achieved by proud (67.75) followed by Biskatali (59.37). At 75 DAT (Table 5), the highest lesion height (11.54) was observed in Control (20.30) and the lowest lesion height (6.39) was found in Proud followed by Biskatali (8.34). The highest percent relative lesion height was recorded in untreated Control followed by Thankuni. The lowest percent relative lesion height was recorded in Proud followed by Thankuni. The highest percent reduction of relative lesion height over control was achieved by proud (73.39) followed by Biskatali (67.26). Similar type of results were observed at 95 DAT. At 95 DAT, lowest number of tiller infection and percent tiller infection was observed by Proud followed by Biskatali and Tulsi (Table 6).

Table 4. Efficacy of some plant extracts on the relative lesion height of sheath blight rice cv. (BRRI dhan $49)$ at 55 days after transplanting (DAT)

\begin{tabular}{lcccc}
\hline \multicolumn{1}{c}{ Treatments } & $\begin{array}{c}\text { Plant height } \\
(\mathrm{cm})\end{array}$ & $\begin{array}{c}\text { Lesion height } \\
(\mathrm{cm})\end{array}$ & $\begin{array}{c}(\%) \text { Relative lesion } \\
\text { height }\end{array}$ & $\begin{array}{c}\text { (\%) Reduction of relative lesion } \\
\text { height over control }\end{array}$ \\
\hline $\mathrm{T}_{1}$ (Control) & 26.88 & $11.54 \mathrm{a}$ & $42.69 \mathrm{a}$ & - \\
$\mathrm{T}_{2}$ (Tulsi) & 30.75 & $6.54 \mathrm{e}$ & $21.28 \mathrm{~d}$ & 50.15 \\
$\mathrm{~T}_{3}$ (Nishinda) & 28.70 & $7.24 \mathrm{~d}$ & $25.33 \mathrm{c}$ & 40.66 \\
$\mathrm{~T}_{4}$ (Thankuni) & 29.37 & $7.83 \mathrm{c}$ & $26.71 \mathrm{c}$ & 37.44 \\
$\mathrm{~T}_{5}$ (Biskatali) & 30.77 & $5.31 \mathrm{f}$ & $17.35 \mathrm{e}$ & 59.37 \\
$\mathrm{~T}_{6}$ (Proud) & 30.94 & $4.28 \mathrm{~g}$ & $13.77 \mathrm{f}$ & 67.75 \\
Level of significance & $*$ & $*$ & -
\end{tabular}

Data represent the means of three replications. * Significant at $5 \%$ level of probability.

Table 5. Efficacy of some plant extracts on the relative lesion height of sheath blight rice cv. (BRRI dhan 49) at 75 days after transplanting (DAT)

\begin{tabular}{lcccc}
\hline \multicolumn{1}{c}{ Treatments } & $\begin{array}{c}\text { Plant height } \\
(\mathrm{cm})\end{array}$ & $\begin{array}{c}\text { Lesion height } \\
(\mathrm{cm})\end{array}$ & $\begin{array}{c}(\%) \text { Relative lesion } \\
\text { height }\end{array}$ & $\begin{array}{c}\text { (\%) Reduction of relative } \\
\text { lesion height over control }\end{array}$ \\
$\mathrm{T}_{1}$ (Control) & 54.81 & $20.30 \mathrm{a}$ & $37.07 \mathrm{a}$ & - \\
$\mathrm{T}_{2}$ (Tulsi) & 62.94 & $10.48 \mathrm{~d}$ & $16.50 \mathrm{e}$ & 45.15 \\
$\mathrm{~T}_{3}$ (Nishinda) & 58.77 & $12.33 \mathrm{c}$ & $20.78 \mathrm{~d}$ & 40.99 \\
$\mathrm{~T}_{4}$ (Thankuni) & 57.28 & $12.36 \mathrm{c}$ & $21.81 \mathrm{c}$ & 67.26 \\
$\mathrm{~T}_{5}$ (Biskatali) & 64.70 & $8.34 \mathrm{e}$ & $12.08 \mathrm{f}$ & 73.39 \\
$\mathrm{~T}_{6}$ (Proud) & 65.18 & $6.39 \mathrm{f}$ & $9.87 \mathrm{~g}$ & - \\
\hline Level of significance & $*$ & $*$ & $*$ & \\
\hline
\end{tabular}

Data represent the means of three replications. ${ }^{*}=$ Significant at $5 \%$ level of probability.

Table 6. Efficacy of some plant extracts on the relative lesion height of sheath blight rice cv. (BRRI dhan 49) at 95 days after transplanting (DAT)

\begin{tabular}{lcccc}
\hline \multicolumn{1}{c}{ Treatments } & $\begin{array}{c}\text { Plant height } \\
(\mathrm{cm})\end{array}$ & $\begin{array}{c}\text { Lesion height } \\
(\mathrm{cm})\end{array}$ & $\begin{array}{c}(\%) \text { Relative lesion } \\
\text { height }\end{array}$ & $\begin{array}{c}\text { (\%) Reduction of relative } \\
\text { lesion height over control }\end{array}$ \\
\hline $\mathrm{T}_{1}$ (Control) & 83.15 & $33.48 \mathrm{a}$ & $40.74 \mathrm{a}$ & - \\
$\mathrm{T}_{2}$ (Tulsi) & 91.96 & $11.71 \mathrm{~d}$ & $12.65 \mathrm{~d}$ & 68.94 \\
$\mathrm{~T}_{3}$ (Nishinda) & 86.81 & $13.71 \mathrm{c}$ & $15.70 \mathrm{c}$ & 61.24 \\
$\mathrm{~T}_{4}$ (Thankuni) & 88.89 & $14.04 \mathrm{c}$ & $15.92 \mathrm{c}$ & 60.92 \\
$\mathrm{~T}_{5}$ (Biskatali) & 92.62 & $8.98 \mathrm{e}$ & $9.72 \mathrm{e}$ & 76.15 \\
$\mathrm{~T}_{6}$ (Proud) & 92.71 & $6.89 \mathrm{f}$ & $7.79 \mathrm{f}$ & 80.87 \\
\hline Level of significance & $*$ & $*$ & $*$ & - \\
\hline
\end{tabular}

Data represent the means of three replications. ${ }^{*}=$ Significant at $5 \%$ level of probability. 


\section{Discussion}

The effect of different plant extracts on number of tillers per hill, number of infected tillers per hill and percent tiller infection of sheath blight of rice cultivar BRRI dhan 49 was estimated at three different time points of 55, 75 and 95 day after transplanting (DAT). Different treatments have some affects on number of tillers per hill (Table 1-3) and plant height (Table 4-6) but not differed significantly by statistical analysis. These results indicate that plant extracts have little effect on plant physiological characters like plant height and tiller numbers. But plant extracts have great effects in reducing plant disease in the field and seed infection.

In the experiment, reduction of tiller infection (\%) and relative lesion height (\%) by using standard fungicide, Proud (Propiconazole) was significantly lower than that of the extracts. But Biskatali extract was found effective like Propiconazole. The finding are consistent with data obtained from previous studies (Kummee and Intaraksa, 2008; Plodpai et al., 2013). Khoa et al. (2011) reported the diseasereducing effect of Chromolaena odorata extract on sheath blight and other rice diseases. Nguefack et al. (2013) found that plant extracts and an essential oil are effective for controlling rice disease, tillering, number of panicles and yield increase. Thus, extract of Biskatali, Thankuni, Nishinda and Tulsi are effective for reducing sheath blight incidence like recommended fungicide, Propiconazole.

In Bangladesh several plant extracts were studied in vitro as seed treatments for controlling seed infection. Khan and Kumar (1992) found that seed treatment with the garlic extract, neem, gagra, vatpata, bishkatali leaf extracts reduced seed-borne prevalence and increased germination percentage of wheat seeds. Rahman et al. (1998) reported that bishkatali extract were effective against seed-borne fungi of wheat. Bishkatali leaf extract showed promising effect against seed borne fungi of rice (Bhuiyan et al. 2013, Faruq et al. 2014). Tulsi (Ocimum sanctum) was also found promising plant extracts for controlling sheath blight of rice. Tulsi is preeminent medicinal plant and scientific research is now confirming its beneficial effects (Cohen, 2014). Dheeba et al. (2015) published that tulsi leaf extract is effective against early blight of tomato. In a previous study, it was found that Thankuni and Nishinda were effective plant extracts inhibiting Fusarium caerulium causing dry rot disease of potato (Rifat, 2014). Thus, aqueous plant extracts of Tulsi, Nishinda, Thankuni and Biskatali are effective to control sheath blight of rice. Among the plant extracts, biskatali showed highest control of sheath blight disease as like as chemical fungicide.

In the experiment, aqueous extracts of indigenous medicinal plants were evaluated. Sometime plant extracts from organic solvents have been found to give more consistent antimicrobial activity compared to water extract (Parekh et al., 2005). But some cases water extracts also contain some compounds can be used against pathogens. Tannin, water soluble compound, which is found in almost every plant part viz. roots, stems, leaves and fruits, and can be toxic to filamentous fungi, yeasts and bacteria (Scalbert, 1991; Jones et al. 1994). Aqueous extract of medicinal plants may include polysaccharides (e.g., starch), polypeptides, various lectins, tannins and terpenoids are effective as inhibitors of pathogen (Navarro et al., 1996). Thus, water extract of the plant extracts used in the experiment might contain some compounds inhibitory to pathogens, which can be revealed in further research.

\section{References}

Ahmed, M.F., Khalequzzaman, K.M., Islam, M.N., Anam, M.K. and Islam, M.T. 2002. Effect of plant extracts against Bipolaris oryzae of rice under in vitro conditions. Pakistan Journal of Biological Sciences, 5 (4) : 442-445.

Ahmed, M., Hossain M., Hassan, K. and Dash, C.K. 2013. Efficacy of Different Plant Extract on Reducing Seed Borne Infection and Increasing Germination of Collected Rice Seed Sample. Universal Journal of Plant Science, 1(3): 66-73, 2013

Akter, T. and Jahan, M. 2013. Toxicity effect of commonly used indigenous plant extracts in controlling rice moth, Sitotroga cerealella Oliv. in stored rice grain. International Journal of Sustainable Agriculture, 5 (1): 10-15.

Amin, M.R., Shahjahan, M., El-Taj, H.F., Iqbal, T.M.T. and Hossain, M.A. 2000. Use of akanda, biskatali and neem leaves as botanical insecticides against lesser grain borer. Bangladesh Journal of Entomology, 10:1-13.

Ansari, M.M. 1995. Control of sheath blight of rice by plant extracts. Indian Phytopath. 48: 268-270.

Ashrafuzzaman, M.H. and Khan, A.R. 1992. Antifungal activity in vitro of some plant extracts on Rhizoctonia solani. Bangladesh J. Sci. Res. 10 (2): 243-244. 
Bhuiyan, M.R., Rashid, M.M., Khan M.A.I., Hoque, M., Nessa, B., Rafii, M.Y., Latif, M.A. 2013. Eco-friendly management of seed borne fungi for sustainable crop production. Life Science Journal 10(4): 1640-1650.

Cohen, M.M. 2014. Tulsi - Ocimum sanctum: A herb for all reasons. J Ayurveda Integr Med. 2014 Oct-Dec; 5(4): $251-259$.

Cowan, M.M. 1999. Plant products as antimicrobial agents. Clinical Microbiology Reviews, 12: 564-582.

Dash, S.C. and Panda, S. 1984. Chemical control of rice sheath blight disease. Indian Phytopathology 37: 79-82.

Dheeba, B., Niranjana, R., Sampathkumar, P., Kannan, K. and Kannan, M. 2015. Efficacy of Neem (Azadirachta indica) and Tulsi (Ocimum sanctum) Leaf Extracts Against Early Blight of Tomato. Proc. Natl. Acad. Sci., India, Sect. B Biol.

Dixon, R.A. 2001. Natural products and plant disease resistance. Nature, 411, 843e847.

FAO (Food and Agriculture Organization of the United Nations). 2010. FAOSTAT Online Statistical Service. Available at:. FAO, Rome http://faostat.fao.org.

Faruq, A.N., Rahman, M.A., Aminuzzaman, F.M., Mamun-ur-Rashid, M. and Hoque, S. 2014. In Vitro Evaluation of Plant Extracts against seed borne bacteria and fungi of Hybrid Rice, App. Sci. Report. 8 (2), 2014: 61-68.

Islam M.S., Uzzal, M.S.I., Mallik, K. and Monjil, M.S. 2013. Management of seed mycoflora on mesta (Hibiscus sabdariffa) by seed washing, garlic extract and Knowin. Progress. Agric, 24 (1\&2): 1-7.

Jones, G.A., McAllister, T.A., Muir, A.D. and Cheng, K.J. 1994. Effects of sainfoin (Onobrychis viciifolia scop.) condensed tannins on growth and proteolysis by four strains of ruminal bacteria. Appl Environ Microbiol., 60:1374-1378.

Kannaiyan, S. and Prasad, N.N. 1984. Effect of foliar spray of certain fungicides on the control of sheath blight of rice. Madras Agricultural Journal 71: 111-114.

Khan, M.I. and Kumar, R. 1992. Antifungal activity of leaf extract of Neem on seed mycoflora of wheat, Indian J. Seed Abs, 15(7):299.

Khoa, N.D., Thúy, P.T.H., Thủy, T.T.T., Collinge, D.B. and Jørgensen, H.J.L. 2011. Disease reducing effect of Chromolaena odorata extract on sheath blight and other rice diseases. Phytopathology 101, 231e240.

Kummee, S. and Intaraksa, N. 2008. Antimicrobial activity of Desmos chinensis leaf and Maclura cochinchinensis wood extracts. Songklanakarin J. Sci. Technol. 30, 635e 639.

Lanzotti, V., Romano, A., Lanzuise, S., Bonanomi, G. and Scala, F. 2012. Antifungal saponins from bulbs of white onion, Allium cepa L., Phytochemistry 74, 133e139.

Latif, M.A., Badsha, M.A., Tajul, M.I., Kabir, M.S., Rafii, M.Y. and Mia, M.A.T. 2011. Identification of genotypes resistant to blast, bacterial leaf blight, and efficacy of seed treating fungicides against blast disease of rice. Sci. Res. Essays, 6: 2804-2811.

Navarro, V., Villarreal, M.L., Rojas, G. and Lozoya X. 1996. Antimicrobial evaluation of some plants used in Mexican traditional medicine for the treatment of infectious diseases. J Ethnopharmaco., 53:143-147.

Nguefack, J., Wulff, G.E., Dongmo, J.B.L., Fouelefack, F.R., Fotio, D., Mbo, J. and Torp J. 2013. Effect of plant extracts and an essential oil on the control of brown spot disease, tillering, number of panicles and yield increase in rice. Eur $J$ Plant Pathol, 137:871-882

Ou, S.H. 1985. Rice Diseases. Common Wealth Mycology Institute. Richmond. Surrey. Great Britain. pp. 3-10.

Parekh, J., Jadeja, D. and Chanda, S. 2005. Efficacy of aqueous and methanol extracts of some medicinal plants for potential antibacterial activity. Turkish Journal of Biology, 29: 203-210.

Peshin, R., Dhawan. A.K., Guleria, S. and Tiku, A.K. 2009. Botanicals in Pest Management: Current Status and Future Perspectives. Integrated Pest Management: Innovation-Development Process. Springer, Netherlands.

Plodpai, P., Chuenchitt, S., Petcharat, V., Chakthong, S. and Voravuthikunchai, S.P. 2013. Anti-Rhizoctonia solani activity by Desmos chinensis extracts and its mechanism of action. Crop Protection, 43: 65-71.

Rahman, G.M.M., Islam, M.R. and Wadud, M.A. 1999. Seed treatment with plant extracts and hot water: a potential biophysical method of controlling seed borne infection of wheat. Bangladesh J. of Training and Development, 12(1-2): 185-190.

Rajput, R.L. and Bartaria, A.M. 1995. Reaction of rice cultivars to brown spot. Agric. Sci. Dig. Karnal, 15: 205-206.

Rifat, M.H. 2014. Study on market diseases of potato and effect of some plant extracts on Fusarium caeruleum. MS thesis, Department of Plant Pathology, Bangladesh Agricultural University, Mymensingh. http://180.211.163.203:8080/ xmlui/bitstream/handle/123456789/329/P\%20PAT H -768.pdf?sequence=1\&isAllowed=y.

Rout, S., Thatoi, H.N. and Tewari, S.N. 2013. Combating sheath blight pathogen (Rhizoctonia solani) of rice with Aegle marmelos extract based Amalab, a formulated botanical product. Indian Phytopath, 66 (2):168-171.

San-Aye, S. and Matsumoto, M. 2011. Effect of some plant extracts on Rhizoctonia spp. and Sclerotium hydrophilum. J. Med. Plants Res. 5, 3751e3757.

Savary, S., Horgan, F., Willocquet, L. and Heong, K.L. 2012. A review of principles for sustainable pest management in rice. Crop Prot., 32, 54e 63.

Scalbert, A.1991. Antimicrobial properties of tannins. Phytochemistry., 30:3875-3883.

Shahjahan, A.K.M., Sharma, N.R., Ahmed, H.U. and Miah, S.A. 1986. Yield loss in modern rice varieties of Bangladesh due to sheath blight. Bangladesh J. Agril. Res., 11(2): 82-90.

Zheng et al. 2013. The evolution and pathogenic mechanisms of the rice sheath blight pathogen. Nature Communications 4 , Article number: 1424. Doi: 10.1038/ncomms2427. 